\title{
SYMPOSIUM
}

\section{Phase specific strategies for the prevention, control, and elimination of sexually transmitted infections: case study in Lambeth, Southwark, and Lewisham, London, UK}

\section{N Low}

Lambeth, Southwark, and Lewisham are three London boroughs that probably have the worst set of indicators of sexual health in the United Kingdom. This area is used to illustrate an urban epidemic of bacterial sexually transmitted infections in an industrialised country with well developed public health infrastructure, and the generalisability of the phase specific model for prevention and control of sexually trasmitted infections. The results show that national strategies for preventing and controlling sexually transmitted infections comprise a limited repertoire of activities that fit with those suggested by the phase specific model. Specific strategies for men and for young black heterosexuals in the most heavily affected areas should be developed. There is, however, insufficient empirical evidence about whether particular interventions introduced at different epidemic stages are effective.

Correspondence to: $\mathrm{N}$ Low, Department of Social Medicine, University of Bristol, Canynge Hall, Whiteladies Road, Bristol BS8 2PR, UK ;

nicola.low@bristol.ac.uk

Accepted

30 November 2001
W asserheit and Aral have described the course of epidemics of gonorrhoea and syphilis in the USA and temporal associations between changes in rates of infection, public health interventions, and the populations involved in the spread of infection (see table 1). ${ }^{1}$ This model should be generalisable to other settings, including those in different countries. Lambeth, Southwark, and Lewisham are three boroughs in London, England, that probably bear the highest burden of sexually transmitted infections in the United Kingdom. This area is used to illustrate an urban epidemic of bacterial sexually transmitted infections in an industrialised country with a well developed public health infrastructure. The social context of the area and the local epidemiology of gonorrhoea and chlamydia are described first. Local and national control strategies are then discussed with reference to the epidemic phase.

\section{SOCIAL CONTEXT AND HEALTH SERVICES}

Lambeth, Southwark, and Lewisham are three adjacent boroughs in inner London (fig 1) with a combined population of about 737000 (the total population of London is around seven million ${ }^{2}$ ). Together they constitute a single administrative area for health service provision and disease surveillance.
Demographic composition of the population Ethnic group

London is home to half of Britain's minority ethnic population. ${ }^{2}$ The major factor shaping London's ethnic composition has been post-world war 2 migration. Lambeth, Southwark, and Lewisham emerged as one of the main locations of the black community, and Brixton, in Lambeth, is known as the "centre of Black Britain".

Ethnic group is classified according to self assigned categories that combine national, racial, and ethnic characteristics, introduced in the 1991 census (table 2). The black population is divided into three broad groups: black Caribbean, black African, and black other. Table 2 shows the distribution of the populations of Lambeth, Southwark, and Lewisham compared with England and Wales. The black population tends to live in certain parts of the boroughs but there are no "ghettos" where a single ethnic group forms over $80 \%$ of the population of a local residential area, ${ }^{2}$ in contrast to African Americans in parts of the United States. Black Caribbeans constitute an average of $34.4 \%$ of the population of areas with a high concentration of this ethnic group, but only $2.6 \%$ of London's black Caribbean population live in such areas. ${ }^{2}$

Births and deaths

The population of Lambeth, Southwark, and Lewisham is, on average, younger than that of the country as a whole. Figure 2 shows that young adults aged 15 to 34 years comprise $34 \%$ of the population of those boroughs, compared with $28 \%$ for England and Wales. This pattern reflects population mobility, including in-migration of young adults, and results in a larger population at risk of sexually transmitted infections. Fertility (66.3 live births/1000 women aged 15 to 44 years in 1996) is higher than in England and Wales as a whole (60.4), and the abortion rate $(33.3 / 1000$ women 11 years and over in 1996) is the highest in the country (12.1/1000 in England and Wales).

The northern part of the boroughs, Southwark and North Bermondsey, has one of the highest death rates in Great Britain, with a standardised mortality rate for those under 65 years 56\% higher than for the country as a whole. ${ }^{4}$ Compared with the country overall, there were higher percentages of deaths from infectious diseases, including HIV infection, respiratory disease, and accidents and violence in Lambeth, Southwark, and Lewisham in 1997.5

Poverty

In Southwark and North Bermondsey, household income was below $£ 13300$ (US\$20 000) a year in 
Table 1 Course of epidemics of sexually transmitted infections, suggested phase appropriate strategies and the actual control programme in Lambeth, Southwark and Lewisham

\begin{tabular}{|c|c|c|c|c|c|}
\hline \multirow[b]{2}{*}{ Phase } & \multirow[b]{2}{*}{ Description } & \multicolumn{2}{|c|}{ Suggested phase appropriate strategies* } & \multicolumn{2}{|c|}{ Prevention activity in Lambeth, Southwark and Lewisham } \\
\hline & & Maintenance network & Spread network & Maintenance network & Spread network \\
\hline I & Growth & & & & \\
\hline \multirow[t]{5}{*}{ II } & \multirow{5}{*}{$\begin{array}{l}\text { Hyperendemic } \\
\text { (for example } \\
\text { chlamydia) }\end{array}$} & Mass media campaigns & Targeted health promotion & $\begin{array}{l}\text { National television and poster } \\
\text { campaign for chlamydia }\end{array}$ & $\begin{array}{l}\text { Pilot study of community based } \\
\text { outreach intervention }\end{array}$ \\
\hline & & $\begin{array}{l}\text { Detection and treatment } \\
\text { services }\end{array}$ & $\begin{array}{l}\text { Outreach for screening and } \\
\text { treatment }\end{array}$ & $\begin{array}{l}\text { Genitourinary medicine clinics } \\
\text { Screening of all attenders for } \\
\text { chlamydia }\end{array}$ & \\
\hline & & $\begin{array}{l}\text { Provider risk reduction } \\
\text { counselling }\end{array}$ & Peer risk reduction counselling & & \\
\hline & & $\begin{array}{l}\text { Client initiated partner } \\
\text { notification }\end{array}$ & $\begin{array}{l}\text { Health department assisted } \\
\text { partner notification }\end{array}$ & Risk reduction counselling & \\
\hline & & & $\begin{array}{l}\text { Community level behavioural } \\
\text { interventions }\end{array}$ & Client initiated partner notification & \\
\hline \multirow[t]{4}{*}{ III } & \multirow[t]{4}{*}{ Decline } & $\begin{array}{l}\text { Detection and treatment } \\
\text { services }\end{array}$ & Targeted health promotion & & \\
\hline & & $\begin{array}{l}\text { Provider risk reduction } \\
\text { counselling }\end{array}$ & $\begin{array}{l}\text { Outreach for screening and } \\
\text { treatment }\end{array}$ & & \\
\hline & & $\begin{array}{l}\text { Client initiated partner } \\
\text { notification }\end{array}$ & $\begin{array}{l}\text { Peer risk reduction counselling } \\
\text { Health department assisted } \\
\text { partner notification }\end{array}$ & & \\
\hline & & & $\begin{array}{l}\text { Community level behavioural } \\
\text { interventions }\end{array}$ & & \\
\hline \multirow[t]{3}{*}{ IV } & \multirow[t]{3}{*}{$\begin{array}{l}\text { Endemic } \\
\text { (for example } \\
\text { gonorrhoea) }\end{array}$} & $\begin{array}{l}\text { Detection and treatment } \\
\text { services }\end{array}$ & Targeted health promotion & $\begin{array}{l}\text { Genitourinary medicine clinics } \\
\text { Screening of all attenders for } \\
\text { gonorrhoea }\end{array}$ & $\begin{array}{l}\text { Local "Soul Protection" radio and } \\
\text { poster campaign }\end{array}$ \\
\hline & & $\begin{array}{l}\text { Provider risk reduction } \\
\text { counselling }\end{array}$ & $\begin{array}{l}\text { Outreach for screening and } \\
\text { treatment }\end{array}$ & & Training for youth workers \\
\hline & & $\begin{array}{l}\text { Client initiated partner } \\
\text { notification }\end{array}$ & $\begin{array}{l}\text { Peer risk reduction counselling } \\
\text { Health department assisted } \\
\text { partner notification } \\
\text { Community level behavioural } \\
\text { interventions }\end{array}$ & $\begin{array}{l}\text { Risk reduction counselling } \\
\text { Client initiated partner notification }\end{array}$ & $\begin{array}{l}\text { Condom promotion events } \\
\text { Pilot study of community based } \\
\text { outreach intervention }\end{array}$ \\
\hline
\end{tabular}

$83 \%$ of households, compared with a national average of $£ 19460$ (US\$30 000). ${ }^{4}$ There are marked inequalities in levels of material deprivation within Lambeth, Southwark, and Lewisham, with the most deprived wards in the north and the least deprived in the south of the boroughs.

\section{Sexual behaviour}

The largest population based survey of sexual behaviour among black minority ethnic groups to date was carried out in 2000 in the area of Lambeth, Southwark, and Lewisham with the highest rates of gonorrhoea. ${ }^{6}$ In this, 222 black Caribbeans, 164 black Africans, and 77 white men and women aged 16 to 25 years were interviewed, representing a response rate of $58 \%$. The survey showed higher levels of sexual risk behaviour than respondents of a similar age in the national survey of sexual attitudes and lifestyles in 1991. ${ }^{7}$ In Lambeth, Southwark, and Lewisham the median age at first sexual intercourse

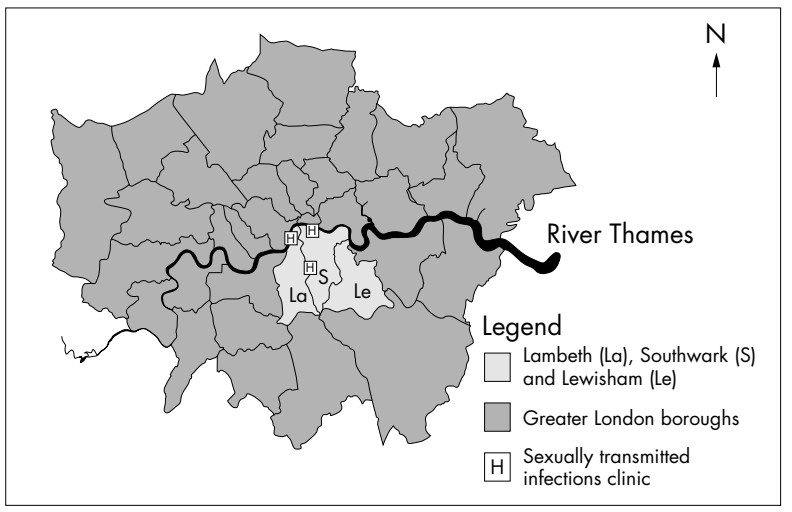

Figure 1 Location of boroughs of Lambeth, Southwark, and Lewisham in Greater London, UK. was 16 years for women in all three ethnic groups and white men, and 15 years for black Caribbean and African men, lower than in the national survey (17 years for both men and women). Respondents in Lambeth, Southwark, and Lewisham reported about twice as many lifetime sexual partners (black Caribbean and white women four, black African women three, black Caribbean and African men eight, white men six) as 16 to 24 year olds in the national survey (two for women, three for men).

The survey also examined sexual mixing patterns according to ethnic group. ${ }^{8}$ Mixing was largely assortative, with the lowest proportion of partners from the same ethnic group chosen by black African men (38\%) and the highest proportion by white men $(100 \%)$. About a quarter of men from black ethnic groups had white partners, whereas fewer than $10 \%$ of black women had white partners.

\section{Sexual health service provision}

The NHS is funded centrally from general taxation and is free at the point of delivery. The private sector in the United Kingdom accounts for only a small proportion of all health care. Genitourinary medicine is a subspecialty of general medicine, with primary responsibility for the management of sexually transmitted infections including HIV. Sexual health services are organised to facilitate rapid and confidential access, so treatment is free and direct self referral is encouraged, in contrast to access to all other hospital specialists, which takes place through referral by a general practitioner. The Venereal Diseases Act of 1916 established a national network of genitourinary medicine clinics in each health district. Figure 1 shows the three clinics in Lambeth, Southwark, and Lewisham. General practitioners and gynaecologists manage a relatively small but undefined proportion of cases of sexually transmitted infections in London and these are not included in surveillance statistics. 


\begin{tabular}{|c|c|c|c|c|c|c|}
\hline Ethnic group & Description & Lambeth & Southwark & Lewisham & $\begin{array}{l}\text { Lambeth, } \\
\text { Southwark and } \\
\text { Lewisham }\end{array}$ & $\begin{array}{l}\text { England and } \\
\text { Wales }\end{array}$ \\
\hline White & & 69.7 & 75.6 & 78.0 & 74.3 & 94.1 \\
\hline Black Caribbean & $\begin{array}{l}98 \% \text { reporting themselves as black } \\
\text { Caribbean were born in the Caribbean } \\
\text { or United Kingdom. }\end{array}$ & 12.6 & 8.3 & 10.1 & 10.4 & 1.0 \\
\hline Black African & $\begin{array}{l}77 \% \text { reporting themselves as black } \\
\text { African were born in West Africa or the } \\
\text { United Kingdom. }\end{array}$ & 6.6 & 7.2 & 3.7 & 5.8 & 0.4 \\
\hline Black Other & $\begin{array}{l}84 \% \text { reporting themselves as black Other } \\
\text { were born in the United Kingdom, } \\
\text { mainly to Caribbean parents. Also } \\
\text { includes blacks of mixed ethnic origin. }\end{array}$ & 2.7 & 2.2 & 2.5 & 2.5 & 0.4 \\
\hline All Black groups & & 21.9 & 17.7 & 16.3 & 18.7 & 1.8 \\
\hline Asian & $\begin{array}{l}\text { Includes Indian, Pakistani, Bangladeshi, } \\
\text { Chinese and other Asian, including East } \\
\text { African Asian. }\end{array}$ & 6.1 & 5.0 & 4.1 & 5.1 & 3.4 \\
\hline Other & & 2.3 & 1.7 & 1.6 & 1.9 & 0.6 \\
\hline All minorities & & 30.3 & 24.4 & 22.0 & 25.7 & 5.8 \\
\hline
\end{tabular}

Source: Office for National Statistics, 1991 census.

*Percentages may not total 100 owing to rounding.

\section{BACTERIAL SEXUALLY TRANSMITTED INFECTIONS IN LAMBETH, SOUTHWARK AND LEWISHAM}

Lambeth, Southwark, and Lewisham comprise $1.5 \%$ of the population of England but bear a disproportionate burden of sexually transmitted infections. In 1999, the three local clinics accounted for $13 \%$ of gonorrhoea, $6 \%$ of chlamydia, and $5 \%$ of first attack herpes simplex reported in England, ${ }^{9}$ and 29\%, $16 \%$, and $16 \%$, respectively, of cases diagnosed in London. The proportion of gonorrhoea cases reported from these three clinics was slightly lower than in 1995 (16\%), but figures for chlamydia and herpes cases did not change. ${ }^{10}$ Over the same period, reported cases of gonorrhoea and chlamydia across the country rose by $50 \%$ and $70 \%$, respectively, but cases of herpes only increased by $1 \%$. The distribution of gonorrhoea therefore seems to have become slightly more diffuse over the past five years, although Lambeth, Southwark, and Lewisham still account for a substantial proportion of all cases of sexually transmitted infections.

\section{Epidemiology of gonorrhoea and chlamydia}

Population based rates of gonorrhoea and chlamydia at the level of a single health authority are not routinely available because the sexually transmitted infection surveillance system in England and Wales only collects aggregated data, which are not stratified by area of residence or ethnic group. The system is adequate for monitoring overall clinic workload $^{11}$ and it ensures complete anonymity for patients, but its limitations have allowed inner city epidemics of bacterial sexually transmitted infections to go unnoticed for years. $^{1213}$

The data presented here are taken from a two year cross sectional study of cases attending genitourinary clinics across London. ${ }^{14}{ }^{15}$ From 1 January 1994 to 31 December 1995, 1996 episodes of gonorrhoea and 1376 episodes of chlamydia in residents of Lambeth, Southwark, and Lewisham were analysed. Data for chlamydia include women only, because testing for chlamydia in men was not universal at the time of the study. All male episodes are considered together because sexual orientation data were missing for over half the cases. Episode based rates of infection (with 95\% confidence intervals (CI) calculated to take clustering into account) are presented where possible to reflect the burden of disease in the population. Person based data were used to calculate age standardised rates in small geographical areas.

Overall rates of gonorrhoea in men and women and chlamydia in women in Lambeth, Southwark, and Lewisham residents aged 15 to 59 years in 1994-95 were 288,147 , and 296 per 100 000, compared with 42,21, and 95 per 100000 in England and Wales in the same year. ${ }^{15-17}$

Rates of infection by age and ethnic group

The highest rates of both infections were among black Caribbean and black other ethnic groups, exceeding 1000/100 000 annually for men with gonorrhoea and women with chlamydia (fig 3). Rates among black Africans were markedly lower
England and Wales

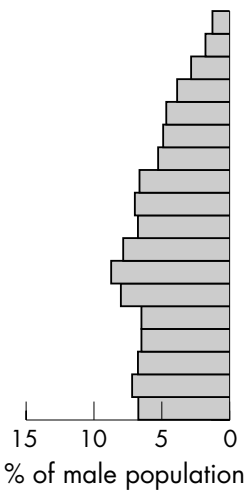

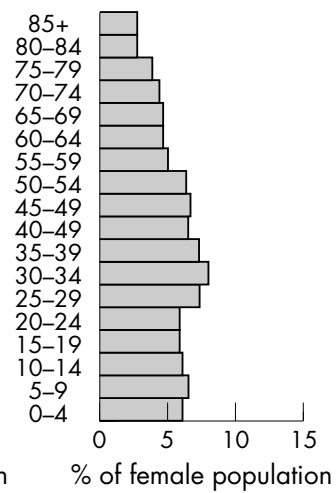

Lambeth, Southwark and Lewisham

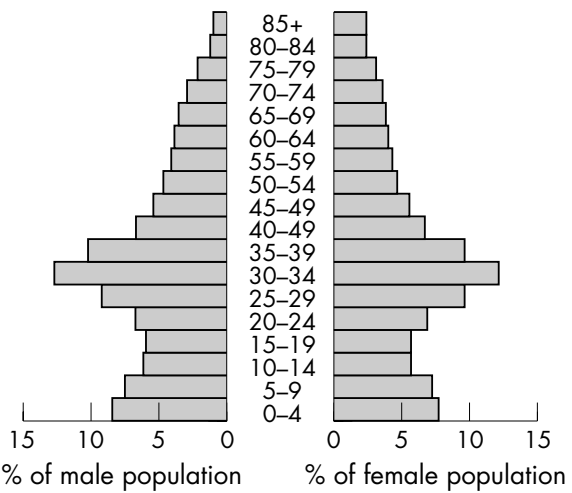

Figure 2 Population pyramids comparing age composition of Lambeth, Southwark, and Lewisham with England and Wales, by sex, 1997. 


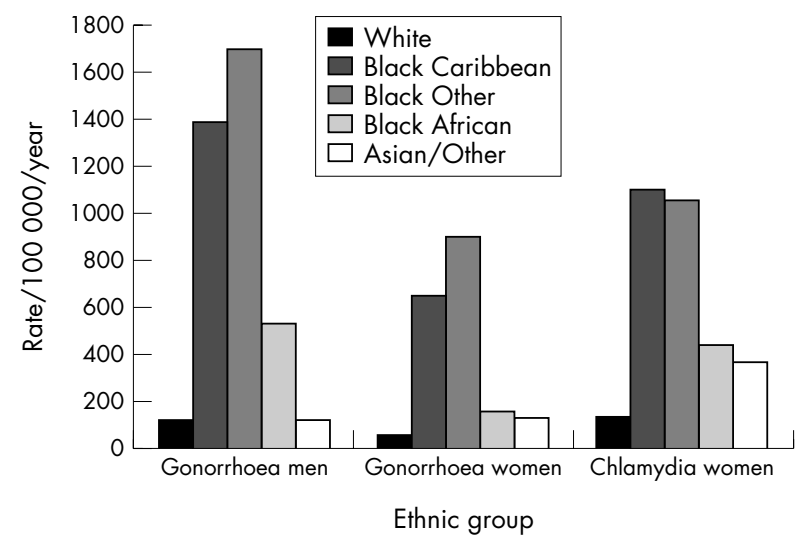

Figure 3 Rates of gonorrhoea and chlamydia, by ethnic group in residents of Lambeth, Southwark, and Lewisham.

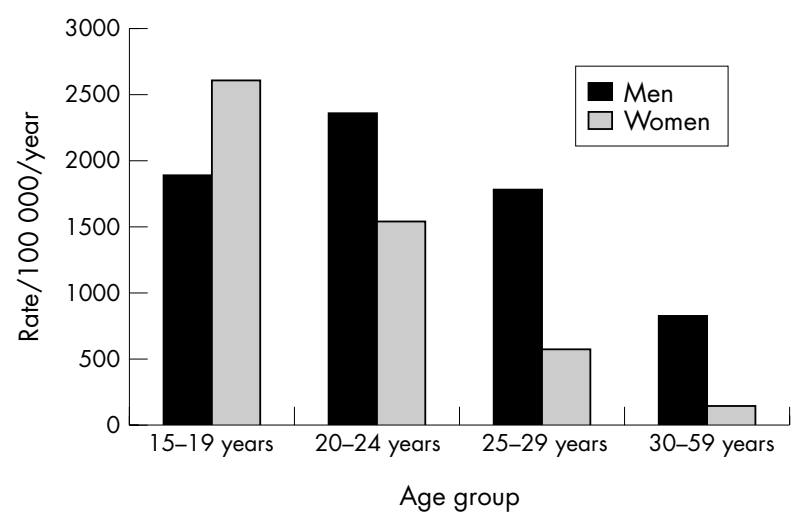

Figure 4 Rates of gonorrhoea by age in black Caribbean men and women resident in Lambeth, Southwark, and Lewisham.

than among the other black ethnic groups, and the lowest rates were in whites.

As with other sexually transmitted infections, teenagers and young adults are at highest risk. Figure 4 shows rates of gonorrhoea by age in black Caribbeans. The highest rates of gonorrhoea were seen among 20 to 24 year old men (2348/100 000; 95\% CI 1965 to 2831) and 15 to 19 year old women $(2612 / 100000 ; 2161$ to 3190$)$. The age distribution was similar for all other ethnic groups. ${ }^{15}$

Gonorrhoea and chlamydia are independently associated with levels of deprivation, but this association is weaker than for ethnic group and age. After controlling for age and deprivation, gonorrhoea rates in black Caribbeans remained substantially higher than in whites. The rate ratio for men was 11.6 (10.1 to 13.4) and for women, 13.2 (10.7 to 16.2). Rates of chlamydia in black Caribbean women were 8.1 times higher (7.1 to 9.3) than in white women, after controlling for other variables. ${ }^{15}$

\section{Geographical distribution}

Rates of gonorrhoea and chlamydia vary widely across the 73 electoral wards of Lambeth, Southwark, and Lewisham. Gonorrhoea rates in men and women combined ranged from $11 / 100000$ to 560/100000 (median 164) annually, and chlamydia rates in women from 28/100 000 to 641/100 000 (median 247). Compared with a study in Winnipeg, Canada, ${ }^{18}$ there were no obvious "break points" in rates that could define core peripheral and adjacent areas of infection. Figure 5 shows the geographical distribution of gonorrhoea in men, with wards with the highest rates clustering in a contiguous area in the west and centre of the boroughs. The distribution of gonorrhoea and chlamydia cases in women was very similar. Gonorrhoea cases were more concentrated than chlamydia cases, with the top quartile of wards for gonorrhoea containing $51.0 \%$ of the cases (901/1768) and for chlamydia, $43.4 \%$ (545/ 1257) ( $\mathrm{p}<0.0001$ by $\chi^{2}$ test). The median gonorrhoea rate in the top quartile of wards was six times higher than the median in the lowest quartile, compared with a threefold difference in rates for chlamydia.

\section{Trends over time}

Trends in reports of sexually transmitted infections in Lambeth, Southwark, and Lewisham follow those of England. Long term data for small areas are not routinely available, so fig 6 shows the time trends for the whole of England from 1971 to 1999. Gonorrhoea cases fell dramatically after the last peak of 59000 cases in 1975 to an all time low of fewer than 10000 cases in 1994, but they have risen again across the country to a total of 15500 cases in $1999 .{ }^{19}$ Chlamydia cases have only been reported since 1988 and trend data are difficult to interpret because of the concurrent increase in testing activity and, since 1998, the introduction of nucleic acid amplification technology. There are no local data examining the number of extra infections diagnosed as a result of the new technology. To compare trends in the two infections, fig 6 shows numbers of episodes of gonorrhoea in men compared with non-specific genital infection as a proxy for chlamydial urethritis. Cases of non-specific genital infection increased consistently until 1986, when gonorrhoea was declining. After a fall in both infections in the mid-1980s, attributed to mass AIDS education campaigns, both conditions have increased but the rise is most pronounced for non-specific genital infection.

\section{EPIDEMIC STAGES OF SEXUALLY TRANSMITTED INFECTIONS AND STRATEGIES FOR CONTROL}

Strategies for prevention and control of sexually transmitted infections have been classified according to their likely impact on the three determinants of the reproductive rate of infection: efficiency of transmission, probability of exposure, and duration of infectiousness. ${ }^{20}$ Wasserheit and Aral have also proposed different strategies for groups among whom the reproductive rate is greater than 1 (spread networks) or equal to 1 (maintenance networks) (table 1 ). ${ }^{1}$ Control strategies suggested as being appropriate for maintenance networks are those that ensure universal access to sexual health services, with targeted interventions aimed at spread networks, irrespective of the stage of the epidemic. A wide range of interventions against sexually transmitted infections has been investigated in observational and randomised trials, and mathematical modelling can provide insights into the effects of different control strategies on an epidemic. ${ }^{21}$ However, there are few empirical data about the relative effectiveness of different strategies implemented at particular stages of an epidemic because complex interventions such as these are difficult to evaluate.

\section{Epidemic phases and control of gonorrhoea and chlamydia in Lambeth, Southwark, and Lewisham Gonorrhoea}

Gonorrhoea rates in the United Kingdom have declined steeply since the 1970s and are in an endemic phase (phase IV) (fig 6), concentrated in areas such as Lambeth, Southwark, and Lewisham. There is a focus of infection among young heterosexuals of black Caribbean extraction in the west and centre of the boroughs (figs 4 and 5). In these areas spread networks appear to exist, with rates of sexual partner change higher than in the country as a whole and evidence of disassortative sexual mixing by ethnic group. ${ }^{68}$

\section{Chlamydia}

Genital chlamydial infection has clearly been present for a substantial length of time but has only been recognised relatively recently. Reporting has been carried out in the United 

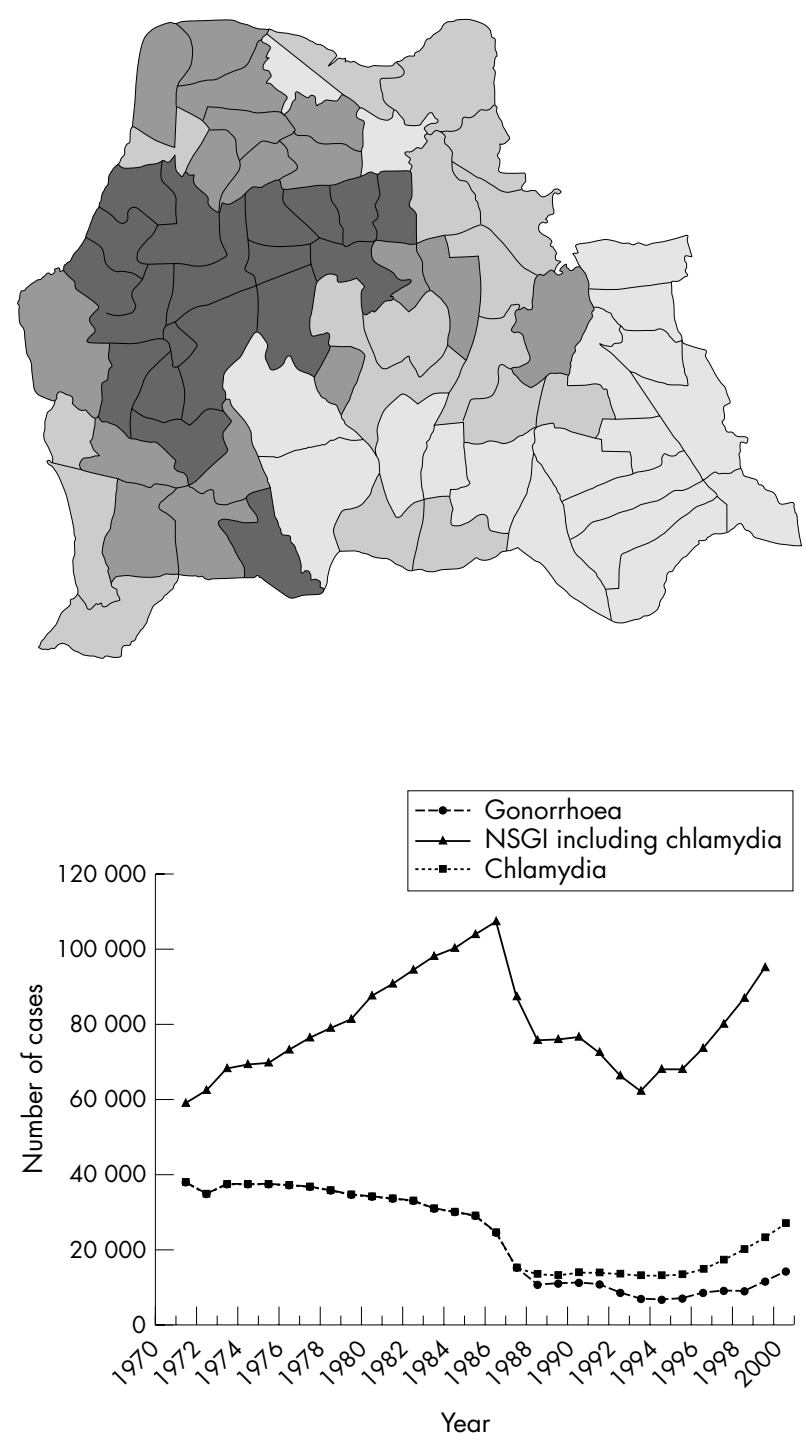

Figure 6 Number of cases of gonorrhoea, non-gonococcal genital infection, and chlamydia in men in England, 1971-1999.

Kingdom since 1988, and any increase in rates (fig 6) therefore partly reflects reporting artefact and, more recently, the impact of more sensitive diagnostic methods. Chlamydia is probably in a hyperendemic (phase II) or declining stage (phase III) of an epidemic. In Lambeth, Southwark, and Lewisham chlamydia is more diffusely distributed than gonorrhoea, with a comparatively small difference between wards with the highest and lowest rates. The areas and groups of people with the highest chlamydia rates overlap substantially with high risk areas for gonorrhoea.

\section{General population control strategy}

In the United Kingdom over at least the last 20 years the control of all sexually transmitted infections other than HIV has relied on opportunistic screening of attenders at genitourinary clinics, treatment and risk reduction counselling for infected individuals, patient initiated partner notification, and reporting of aggregated data. The rise in all sexually transmitted infections across the country since 1995 suggests that these limited measures are inadequate and that previous Government sexual health promotion policy has failed. ${ }^{13} \mathrm{~A}$ new national strategy for sexual health and HIV was launched in 2001 , with more ambitious intentions. ${ }^{22}$ The strategy proposes to widen the availability of diagnosis and treatment for sexu-
Gonorrhoea incidence rate per 100000 males (quartiles)

$20.2-125.9$

$125.9-192.5$

$192.5-311.9$

$311.9-786.3$

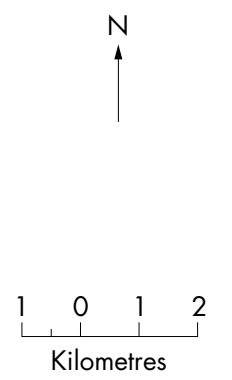

ally transmitted infections by increasing involvement of general practitioners and increasing the community role of sexual health advisers. Extending opportunistic chlamydia testing for women under 25 years in a range of settings was recommended in $1998,{ }^{23}$ but the national strategy recommends including only women having a termination of pregnancy or first cervical smear until full results from a national pilot study and research into methods of screening are available. The planned initiatives are all aimed at young women. Men have usually been excluded from mainstream interventions because they are less likely to use health services, and efforts to reach them are therefore not costeffective. ${ }^{23}{ }^{24}$ As men have larger numbers of sexual partners, and as diagnostic tests that can be performed on male urine are widely available, innovative interventions in nontraditional settings should be designed and evaluated.

In Lambeth, Southwark and Lewisham Health Authority a multidisciplinary sexually transmitted infections working group was convened in 1998 to develop a comprehensive strategy for tackling sexually transmitted infections, HIV infection, and unplanned pregnancy following publication of local data showing alarmingly high rates of gonorrhoea in black minority populations. ${ }^{14}$ While this raised awareness among some health care commissioners and providers, there has been no increase in funding and no major change in the approach to controlling sexually transmitted infections.

\section{Targeted interventions}

Young heterosexuals from black Caribbean backgrounds are at particularly high risk of both gonorrhoea and chlamydia. ${ }^{15}$ Lambeth, Southwark, and Lewisham account for $14 \%$ of gonorrhoea cases in the country and 30\% of those in London, and two thirds of these are in black Caribbeans. This is a population group for whom intensively targeted interventions to diagnose, treat, and prevent bacterial sexually transmitted infections would be highly cost-effective, as well as reducing long standing ethnic inequalities in health status. Despite this, no long term strategy for this group has yet been implemented or been proposed by the national strategy for sexual health. ${ }^{22}$ Interventions should be effective, acceptable, and nonstigmatising. ${ }^{25}$ Geographical targeting of interventions that include everyone but are located in areas with the highest rates of sexually transmitted infections and in places frequented by the target population can avoid charges of negative stereotyping. ${ }^{6}$ In Lambeth, Southwark, and Lewisham several short term activities have been carried out (table 1). A multimedia campaign ("Soul Protection"), suggested as 
being more appropriate for informing the general public about a "new" sexually transmitted infection, ${ }^{1}$ was carried out in 1999 to redress the longstanding failure to recognise the high rates of gonorrhoea in a marginalised population. Training about sexually transmitted infections for youth workers and condom promotion events have taken place. Most recently a novel community intervention combining health promotion with an offer of urine based testing for chlamydia and gonorrhoea to young men and women in further education colleges has been shown to be both acceptable and feasible. ${ }^{26}$ Evidence from rigorously evaluated interventions is, however, still lacking.

\section{CONCLUSIONS}

Epidemics of gonorrhoea and chlamydia are described in a deprived inner city area of a developed country with easily accessible free and confidential sexual health services. Gonorrhoea is in an endemic phase with spread networks occurring among heterosexuals of Caribbean extraction living in a geographically defined area. Chlamydia is a more recently recognised epidemic for which comprehensive national interventions have yet to be implemented. Chlamydia is much more widespread than gonorrhoea, but high rates also occur in black Caribbean teenagers in a geographical core area that corresponds with that for gonorrhoea. Changes in reporting and diagnosis of chlamydia make its epidemic phase difficult to determine simply from its epidemiology. Rates of both infections been increasing over the last six years and it is unclear whether this represents the start of a new epidemic, or secular trends in a declining epidemic owing to a lack of effective targeted interventions in spread networks. Current control strategies for the general population fit with those proposed by the model of Wasserheit and $\mathrm{Aral}^{1}$ but do not appear to be controlling either infection. General population interventions aimed at men, and targeted interventions to reduce the marked ethnic inequalities in sexual health, need to be implemented. There are, however, insufficient data from controlled trials at present to guide policymakers about the most effective phase specific interventions.

\section{REFERENCES}

1 Wasserheit JN, Aral SO. The dynamic topology of sexually transmitted disease epidemics: implications for prevention strategies. J Infect Dis 1996; 174(suppl 2):S201-13

2 Storkey M, Maguire J, Lewis R. Cosmopolitan London - past, present and future. London: London Research Centre, 1997.

3 Teague A. Ethnic group; first results from the 1991 Census. Popul Trends 1993;72:12-17.
4 Shaw M, Dorling D, Gordon D, et al. The widening gap. Health inequalities and policy in Britain. Bristol: The Policy Press, 1999.

5 Director of Public Health. Past, present and future: annual report of the Director of Public Health, 1997-1998. London: Lambeth, Southwark and Lewisham Health Authority, 1998.

6 Low N, Sterne J, McKevitt C, et al. Investigating ethnic and geographic variations in sexual health in South East London. Final report (unpublished), July 2001.

7 Johnson AM, Wadsworth J, Wellings K, et al. Sexual attitudes and lifestyles. Oxford: Blackwell Scientific Publications, 1994.

8 Low N, Massey T, Sterne JA. Who's having sex with whom? MSSVD Spring Meeting, Belfast, 24-27 May 2001.

9 Public Health Laboratory Service. Selected diagnoses, by region and clinic, 1999. London: PHLS AIDS and STD Centre and CDSC (Welsh Unit), 2000.

10 Government Statistical Service. Sexually transmitted diseases, England 1995: new cases seen at NHS genito-urinary medicine clinics, 14 London: Department of Health, 1996.

11 Catchpole MA, Harris JR, Renton A, et al. Surveillance of sexually transmitted infections: fit for purpose? Int J STD AIDS 1999;10:493-4.

12 de Cock KM, Low N. HIV and AIDS, other sexually transmitted diseases and tuberculosis in ethnic minorities in the United Kingdom: is surveillance serving its purpose? BM 1997;314:1747-51.

13 Adler MW. Sexual health - a Health of the Nation failure. BM 1997;314:1743-7.

14 Low N, Daker-White G, Barlow D, et al. Gonorrhoea in inner London: results of a cross sectional study. BM 1997;314:1719-23.

15 Low N, Sterne JA, Barlow D. Inequalities in rates of gonorrhoea and chlamydia between black ethnic groups in South East London: cross-sectional study. Sex Transm Inf 2001;77:15-20.

16 Communicable Disease Surveillance Centre. Sexually transmitted diseases quarterly report: genital infection with Chlamydia trachomatis in England and Wales. Commun Dis Rep CDR Wkly 1995;5:122-3.

17 Communicable Disease Surveillance Centre. Sexually transmitted diseases quarterly report: gonorrhoea in England and Wales. Commun Dis Rep CDR Wkly 1996;6:110-11.

18 Blanchard JF, Moses S, Greenaway C, et al. The evolving epidemiology of chlamydial and gonococcal infections in response to control programs in Winnipeg, Canada. Am J Public Health 1998;88: 1496-502.

19 Johnson AM, Fenton K, Jameson C. Phase specific strategies for the prevention, control, and elimination of sexually transmitted diseases. Background country profile: England and Wales. Sex Transm Infect $2001 ; 78$ (suppl):i125-32.

20 St Louis ME, Holmes KK. Conceptual framework for STD/HIV prevention and control. In: Holmes KK, Sparling PF, Mardh P-A, et al, eds. Sexually transmitted diseases. New York: McGraw-Hill, 1999.

21 Garnett GP, Bowden FJ. Epidemiology and control and curable sexually transmitted diseases: opportunities and problems. Sex Transm Dis 2000;27:588-99.

22 Department of Health. National strategy for sexual health and HIV. London: Department of Health, 2001

23 CMO's Expert Advisory Group on Chlamydia trachomatis. London: Department of Health, 1998.

24 Fenton KA. Screening men for Chlamydia trachomatis infection: have we fully explored the possibilities? Commun Dis Public Health 2000;3:86-9

25 Connell P, McKevitt C, Low N. Sexually transmitted infections among black young people in south east London: results of a rapid ethnographic assessment. Culture Health Sexuality 2001;3:31 1-27.

26 Low N. "You can't tell by looking." Community-based intervention to detect gonorrhoea and chlamydia in young black Caribbeans. Centre for Caribbean Medicine Annual Conference. London, 19-20 June 2001. 